\title{
なぜ薬剤師にヒューマニティ教育が必要なのか？～～医療人教育の立場から〜
}

\author{
有田悦子
}

\section{Why Pharmacists Need Education in the Humanities: A Medical Professional Educator's Viewpoint}

\author{
Etsuko Arita \\ Kitasato University School of Pharmacy; 5-9-1 Shirokane, Minato-ku, Tokyo 108-8641, Japan.
}

(Received August 2, 2019)

\begin{abstract}
Over the past few decades, pharmacists' work has changed from product-centered tasks to patient-centered care. In response to such social changes and needs, the pharmacy education course was also extended from 4 to 6 years, and the importance of the humanities in the curriculum (e.g., medical psychology, medical ethics, and communication) is now recognized. The Model Core Curriculum for Pharmacy Education, 2013 version, described 10 professional competencies for pharmacists (professionalism, patient-oriented attitude, communication skills, interprofessional team care, basic sciences, medication therapy management, community health and medical care, research, lifelong learning, and education and training) and stated that the humanities are a foundation of pharmaceutical education. However, a report by the Pharmaceutical Society of Japan (2014) expressed concern that clinical practice was not connected with knowledge of the humanities. It is educationally meaningful when pharmacists who studied the humanities can then offer the best medical care to patients. In order to utilize knowledge of the humanities in the clinical setting, educators need to provide opportunities for active learning. Furthermore, the humanities are useful to help pharmacists acquire meta-cognition.
\end{abstract}

Key words_ — pharmacy education; humanities; medical psychology; medical ethics; communication; meta-cognition

\section{はじめに}

この数十年の間に，薬剤師に求められる業務は “対物”から“対人”へと大きな変化を遂げてきた. 薬学教育年限も 4 年から 6 年に延長され, “人間” を理解するための心理, 倫理, コミュニケーション 等を含むヒューマニティ教育の重要性が増してきて いる。平成 25 年度改訂モデル・コアカリキュラ ム1)では，「薬剤師として求められる基本的な資質」 として「豊かな人間性と医療人としての高い使命感 を有し，生命の尊さを深く認識し，生涯にわたって 薬の専門家としての責任を持ち，人の命と健康な生 活を守ることを通して社会に貢献する」ことを掲げ, 6 年卒業時に必要とされる 10 の資質を明示してい る（Table 1)。10 の資質のそれぞれが 6 年間の学 習内容と連動しながら醸成されていくことが期待さ れ，ヒューマニティ関連科目はそのすべてのベース

北里大学薬学部（干108-8641 東京都港区白金 5-9-1) e-mail: aritae@ pharm.kitasato-u.ac.jp 本総説は, 日本薬学会第 139 年会シンポジウム S42 で 発表した内容を中心に記述したものである.
となっている. ${ }^{2)}$ 一方で，平成 25 年度に日本薬学会 が全国の薬系大学を対象として実施した改訂薬学教 育モデル・コアカリキュラム「A 基本事項」の実 施状況調査結果 ${ }^{3)}$ では，ヒューマニティ関連科目と 薬剤師業務との間の連続性がそしいことにより，学 習者にとっては心理や倫理，コミュニケーション等 の知識が臨床現場でどのように活用できるのかイ メージがつかない状況が懸念された.

薬学におけるヒューマニティ教育の目的は, それ らが患者に最善の医療の提供するために活かされる ことであり，臨床現場で “使える”知識や技能でな ければ意味がないと考え, 筆者は薬学部卒業後, 大 学院で臨床心理学を学び 30 年間に渡つて薬学教育 におけるヒューマニティ教育を開拓してきた.

そこで本稿では，「なぜ薬剤師にヒューマニティ 教育が必要なのか」について，医療人教育の立場か ら改めて考察していきたい.

\section{1. プラセボ効果から医療人教育へ}

筆者が学生だつた 1980 年代，薬学教育は薬とい う“物質”にフォーカスしたものが中心で，その薬 
Table 1. Professional Competencies for Pharmacists (Model Core Curriculum for Pharmacy Education-2013 version-)

1. Professionalism: Fulfill the legal, ethical, and professional responsibilities of pharmacists.

2. Patient-oriented attitude: Respect the rights of individuals and to promote the health and welfare of patients and consumers.

3. Communication skills: Communicate effectively with patients, consumers, and other healthcare professionals to provide necessary information.

4. Interprofessional team-care: Collaborate with the healthcare teams in hospitals and regional communities.

5. Basic sciences: Understand the effects of medicines and chemicals on living bodies and environments.

6. Medication therapy management: Contribute to the optimal use of medicines through pharmaceutical care.

7. Community health and medical care: Contribute to public health and pharmaceutical hygiene and to enhance community healthcare and home care.

8. Research: Engage in research on drug development and the appropriate use of medicines to improve the healthcare environment.

9. Lifelong learning: Continue lifelong professional development in response to the advance in healthcare.

10. Education and Training: Contribute to the development of the next generation of professional pharmacists.

を用いる当事者である患者という“人”についての 教育は皆無だった。将来, 病院薬剤師として働きた いと考えていた学部 3 年生の頃, たしか「臨床薬理 学」の講義だったと思うが「プラセボ効果」という 言葉と出会つた。「何の薬理作用も持たない物質で も, 飲む人の治療への期待や医療者への信頼感によ り，実際に効果（プラセボ効果）が現れることがあ る」という話を聞いて，患者の心理について強い関 心を持った.「ただ単に患者に薬を渡すだけなら， それが薬剤師である必要はない。物質である薬に, 患者が安心してより効果を感じられるような心理的 な付加価值（プラスのプラセボ効果）を加えるのが これからの薬剤師に求められる役割ではないか?」 と考え, 大学院で臨床心理学を学ぶことを決意し た. 大学院進学と同時に, 大学病院の講座研究員と なり「患者心理とプラセボ効果」をテーマに研究を 開始した。

大学病院で病棟活動に同行する中で，薬剤師が医 学的に“正しい説明”をし，患者はその説明に対し て「わかった」と返事をしていたのにもかかわらず,

実際の服薬行動が伴わないような事例に多々遭遇 し，患者の気持ちを本当に理解することの難しさを 痛感した. “患者心理”を理解するためには目の前 の患者さんの想いをいかに聴き，その想いを共有し た上で，個々の患者に合った情報をいかに伝える か? つまり医療者が患者さんと双方向の“コミュ ニケーション”を取ることが必要であり，そのため には“医療人教育”が重要であると考えた.

\section{2. “対物”から“対人”へ 〜薬剂師を取り巻 く社会情勢の変化}

大学院卒業後, 「患者の心がわかる医療人を育て て」という声かけで母校に戻り, 学生の相談を受け ながら細々と研究を続けていた。

時を同じくして薬剤師を取り巻く社会情勢は大き く動き始め, 1992 年 薬剤師が「医療の担い手」と して医療法に明記され，1996 年 薬剤師法改正で患 者や介護者への情報提供が義務づけられ，2002 年 薬学教育モデル・コアカリキュラムが施行され，基 礎と臨床と並んでヒューマニティ教育が三本柱の 1 つに掲げられた。筆者も 1996 年に開講した「臨床 心理・コミュニケーション論」を担当したのを皮切 りに, 2006 年の 6 年制教育開始とともに, 医療心 理学, 医療倫理学等, ヒューマニティ関連科目すべ てを担当することになつた。 そして前述したように 2013 年には薬学教育モデル・コアカリキュラムが 改訂され, 薬学教育 6 年間で醸成される資質として 「薬剤師として求められる基本的資質 10 項目」が示 され，心理，倫理，コミュニケーション等は「A基

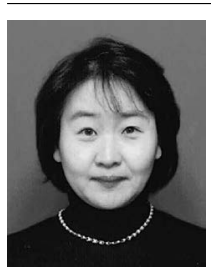

有田悦子
博士 (臨床薬学), 北里大学薬学部薬学 教育研究センター医療心理学部門 准教 授 (公認心理師). 北里大学薬学部を卒 業後, 大学病院研究員, 患者心理と服 薬効果をテーマに東京学芸大学大学院 修了 (教育学修士)。「薬学教育におけ る新たなコミュニケーション教育プロ グラムの構築」にて学位授与. 北里大 学薬学部助手, 講師を経て現職. 30 年 前より薬学教育におけるヒューマニテ イ教育分野の開拓に尽力し, 現在に至 る. 
本事項」に含まれ，医療人として生涯を通して学ぶ べき内容となった.

2015 年には厚生労働省から「患者のための薬局 ビジョン 『門前』から『かかりつけ』そして『地 域』へ」出が発出され，これからの薬剤師に求めら れる姿として「患者に選択してもらえる薬剤師・薬 局となるため，専門性やコミュニケーション能力の 向上を通じ，薬剤の調製などの対物中心の業務か ら，患者・住民との関わりの度合いの高い対人業務 へとシフトを図る」ことが明記され，“対物”から “対人”へという流れは名実ともに決定的なものに なった。

\section{3.“知識”を“実践”によ゙う生かすのか ?}

前述したように，心理や倫理，コミュニケーショ ン等は知識だけを覚えても意味がなく, 臨床現場で 目の前の患者対応に活かされてこそ意味がある。で は，どの段階で，ぞのように生かせるのだろうか？ 以下に具体例を挙げる.

【場面】病棟薬剤師として担当になった患者が 「薬を飲みたくない」と言つている.

Step 1 患者の心理・社会的背景を考える.

コンプライアンスの悪い患者だ，と決めつける前 に，なぜ飲みたくないと言っているのか，患者なり の薬や治療への考え（解釈モデル）があるはずと考 える.ここでは「臨床心理学」の知識が役に立つ.

Step 2 患者のナラティブ（物語）を傾聴する.

患者の気持ちは話してもらわなければわからな い，そこで適切な質問を混ぜながら受容的な態度で 共感しながら聴く。ここでは「コミュニケーション」 の知識や技法が役に立つ.

Step 3 医療者と患者のモラルジレンマを解決す る.

患者の希望と医学的適応が相反する場合, 薬剂師 としてどちらを尊重すべきか悩む場面は多い。その 際に有用なのが生命倫理 4 原則に基づいて状況を整 理し，最善の方策を検討することである。ここでは 「医療倫理学」の知識が役に立つ.

Step 4 患者の意思を尊重した行動変容を促す.

状況が十分に整理されたところで，患者と双方向 のコミュニケーションをとりながら，患者自身が自 発的に健康行動をとれるようなアプローチをする. ここでは「行動科学」の知識やアプローチ方法が役 に立つ。
このように知識と実践をつなぐためには，学習者 が受け身で知識を詰め込む一方向の講義形式だけで は限界がある．具体的な事例に基づいたグループ ディスカッションや深い患者心理を体現した模擬患 者とのロールプレイを用いるなど，学習者が主体 的, 能動的に学べるアクティブ・ラーニングで実際 に体験することによって，知識が実践へとつながる 様々な気づきを得ることができる. ${ }^{5)}$

\section{4. おわりに 〜対人援助職に必要なメ夕認知力}

医療職（対人援助職）は，自分の年齢や経験に関 係なく幅広い年代の “いのち”に直接係わる仕事で ある。そして時に，正解が出ない現実に向き合わな ければならないため, 物事を俯瞰する力 (メ夕認知) が大切になる。 メ夕認知とは, 自己の認知活動（知 覚，情動，記憶，思考など）を客観的に捉え，評価 した上で制御したり，自分の学習をモニタリング し，コントロールしたりすること，と言われてい る. $\left.{ }^{6}\right)$ メ認知を身に付けることは薬剤師自身の安 定につながり，結果として患者の QOL や医療の質 向上に貢献することが期待できる，そのためには， 物事を冷静に多角的に見る力や，自分を客観視する 力が必要と言われており，ここでも，ヒューマニ ティ教育がべースとなる.

筆者が勤務するような私立大学では，少数の教員 で 300 名近い学生に対応せざるを得ない現実もあ り, 効果的な参加型教育や個々の学生に対する適切 な評価の遂行には常に困難が伴う。しかし，患者の 想いを理解し最善の医療を提供できる薬剤師養成の ためにはヒューマニティ教育は肝要であり，教育す る側にも自身のヒューマニティを磨きつつ根気強く 取り組む覚悟が求められている。

利益相反＼cjkstart開示すべき利益相反はない.

\section{REFERENCES}

1) The Pharmaceutical Society of Japan, "Model Core Curriculum for Pharmacy Education2013 version," 2013.

2) The Pharmaceutical Society of Japan, "Heisei 25 nendo Kaitei Yakugakukyoiku Model Core Curriculum no Jisshijokyo ni kansuru Chosa/ Kenkyu"' Hokokusho, March 2019.

3) The Pharmaceutical Society of Japan, "Iryojinyosei toshiteno Yakugakukyoiku 
nikakaru Kyozai ya Kyoikuhouhou no Kaihatsu nikansuru Chosakenkyu'" Hokokusho, May 2014.

4) Ministry of Health, Labour and Welfare, "Kanja no tameno Yakkyoku Vision —“Monzen" kara "Kakaritsuke” soshite “Chiiki” e-," October 2015.

5) Pharmaceutical Communication Society of
Japan, "Humanism for Pharmacist -Attitude, Ethics, Communication," Yodosha Co., Ltd., Tokyo, 2011.

6) Ambrose S. A., Bridges M. W., DiPietro M., Lovett M. C., Norman M. K., "How Learning Works: Seven Research-Based Principles for Smart Teaching," Tamagawa University Press, Machida, 2014, pp. 185-187. 